\title{
ONCE MORE
}

Like when you are washing out a cup you've had flowers in. Someone brought you some, an acquaintance-daisies

which she got at a florist's in January, so that they smelled too rich, too much like someone

missing. Bits of green cling tenaciously to the cup. Water swirls inside. The odor rises

like a coffin lid.

Your mother lifts you up

to see. You are drowning

in the smell of weeping. Someone is singing Nearer My God to Thee.

He is surrounded

by white satin, like a cherished music box above your bed.

You close your eyes tight,

and every trace of flowers

goes under. Then you open them

once more. And then, once more,

it is all over. 